\title{
PENGARUH LINGKUNGAN TEMPAT TINGGAL TERHADAP PERJALANAN BERBELANJA DI KOTA BANDUNG
}

\author{
Tri Basuki Joewono \\ Program Studi Teknik Sipil \\ Universitas Katolik Parahyangan \\ Jln. Ciumbuleit 94, Bandung \\ Tlp. 022-2033691 \\ vftribas@unpar.ac.id
}

\author{
Nabila Putri Larasati \\ Program Studi Teknik Sipil \\ Universitas Katolik Parahyangan \\ Jln. Ciumbuleit 94, Bandung \\ Tlp. 022-2033691 \\ Nabilalaras27@gmail.com
}

\author{
Muhamad Rizki \\ Program Studi Teknik Sipil \\ Universitas Katolik Parahyangan \\ Jln. Ciumbuleit 94, Bandung \\ Tlp. 022-2033691 \\ muhamadrizkitaki@gmail.com
}

\begin{abstract}
The shopping trip for everyone's daily needs is diverse. They have their own reasons to choose a shopping place that suits their needs. The aim of this study is to describe the characteristics of shoppers and their residential environment and to model the relationship of both variables. This study employed data from questionnaires distributed in Bandung City. Data were analyzed using ordinal regression method. The result of the analysis shows that the variables of residential environment condition significantly influence the shopping frequency.
\end{abstract}

Keywords: shopping trip; residential environment; public transportation; shopping frequency.

\begin{abstract}
Abstrak
Perjalanan berbelanja untuk kebutuhan sehari-hari tiap orang berbeda-beda. Banyak alasan yang dimiliki setiap orang untuk memilih tempat belanja yang sesuai dengan keinginan mereka. Tujuan studi ini adalah mendeskripsikan karakteristik pelaku belanja dan lingkungan tempat tinggal serta memodelkan hubungan keduanya. Studi ini menggunakan data hasil penyebaran kuesioner di Kota Bandung. Analisis data menggunakan metode regresi ordinal. Hasil analisis menunjukkan bahwa variabel kondisi lingkungan tempat tinggal berpengaruh secara signifikan terhadap frekuensi berbelanja.
\end{abstract}

Kata-kata kunci: perjalanan berbelanja; lingkungan binaan; kendaraan umum; frekuensi berbelanja.

\section{PENDAHULUAN}

Perjalanan merupakan konsekuensi dari pemenuhan kebutuhan dan keinginan yang perlu difasilitasi dalam lokasi spasial tertentu dalam rentang waktu yang spesifik. Salah satu tujuan perjalanan yang dilakukan adalah kegiatan belanja. Berbelanja sebagai salah satu rangkaian spasial yang berhubungan dengan keputusan terkait lokasi dan perjalanan yang diambil oleh rumah tangga (Vickerman dan Barmby, 1984). Keputusan pelaku belanja di masing-masing rumah tangga berbeda, bergantung pada jenis kebutuhan apa yang ingin dipenuhi. Perjalanan yang dilakukan pun turut beragam sesuai dengan keputusan yang diambil oleh masing-masing pelaku belanja.

Pelaku belanja memiliki kebebasan dalam memilih lokasi belanja. Pola pelaku belanja terutama kelas menengah ke atas yang tidak mau berdesak-desakan di dalam pasar tradisional menghadirkan industri ritel modern yang pada dasarnya memanfaatkan pola tersebut (Soliha, 2008). Saat ini terdapat 3 jenis pasar modern, yaitu minimarket, supermarket, dan 
hypermarket, dengan perbedaan utama terletak pada luas lahan usaha dan jenis barang yang diperdagangkan (Pandin, 2009).

Banyak faktor yang memengaruhi pelaku belanja dalam memilih lokasi belanja. Salah satu di antaranya adalah karakteristik lingkungan. Karakteristik lingkungan tempat tinggal erat kaitannya dengan gaya hidup yang dipilih dan pendapatan rumah tangga. Karakteristik lingkungan yang dirasakan oleh seseorang dapat mencerminkan perbedaan mendasar dalam desain lingkungan.

Meskipun saat ini terdapat peningkatan pengguna aplikasi belanja secara online, belanja secara tradisional masih menarik untuk sebagian masyarakat, karena akses kepada sistem informasi dan komunikasi yang belum merata di Indonesia. Selain aspek infrastruktur sistem informasi dan komunikasi di Indonesia serta fakta bahwa belanja dengan kehadiran secara fisik masih memiliki superioritas dibanding online, penelitian mengenai belanja dengan kehadiran secara fisik masih diperlukan. Dengan kondisi perkotaan, sosial, dan lingkungan yang berbeda, penting untuk menginvestigasi perilaku perjalanan pelaku belanja di negara berkembang, seperti Indonesia. Secara spesifik, berbagai studi di negara maju telah mengindikasi bagaimana pengaruh dari karakteristik lingkungan terhadap perilaku belanja termasuk pemilihan lokasi belanja. Oleh karena itu, studi ini dilakukan dengan tujuan untuk mengetahui hubungan kondisi lingkungan tempat tinggal dengan karakteristik perjalanan belanja di Bandung, Indonesia.

\section{PERJALANAN BELANJA}

Model perjalanan belanja yang dilakukan oleh Arentze et al. (1993) mengasumsikan pelaku belanja melakukan perjalanan dengan tujuan membeli barang dengan jenis tertentu. Kumpulan tujuan belanja dapat ditentukan oleh frekuensi relatif dari pembelian tipe barang yang berbeda dan kecenderungan dalam memanfaatkan peluang untuk belanja multitujuan. Masalah terkait perjalanan berbelanja yang dibahas adalah kejadian ketika individu memiliki pilihan tempat belanja yang tersebar di atas titik-titik diskrit dalam ruang pada jarak tertentu dari rumah mereka. Setiap tempat belanja menawarkan berbagai macam produk yang dikenal oleh pelaku belanja dan pelaku ingin membeli satu set produk yang disediakan oleh toko tersebut. Individu ingin membeli satu set produk tersebut dengan frekuensi pembelian yang berbeda dari waktu ke waktu. Individu memiliki pilihan untuk melakukan perjalanan belanja untuk setiap pembelian secara terpisah (perjalanan satu tujuan) atau secara alternatif para pelaku dapat menggabungkan pembelian barang yang berbeda selama perjalanan (perjalanan multitujuan) untuk mengurangi biaya saat memperoleh barang. Masalah selanjutnya adalah kemampuan memprediksi secara bersamaan jumlah perjalanan multitujuan yang dibuat dalam horizon waktu yang terbatas dan untuk masingmasing pusat perbelanjaan, yaitu peluang pemilihan frekuensi pembelian untuk masingmasing barang yang diberikan. 
Analisis terkait perjalanan berbelanja dilakukan oleh McFadden (1973) yang memisahkannya menjadi tiga tujuan. Pertama, analisis mengenai pemilihan moda perjalanan yang didapat dari pengamatan waktu dan tempat tujuan. Kedua, analisis terkait pemilihan tujuan perjalanan yang didapat dari pengamatan waktu berdasarkan moda. Analisis ketiga adalah mengenai frekuensi perjalanan berbelanja yang didapat dari pengamatan waktu, moda, dan tujuan perjalanan. Saat belanja, pelaku kegiatan belanja harus terlebih dahulu memutuskan untuk memilih tujuan belanja daripada memilih produk yang akan dibeli. Jika keputusan untuk pergi belanja dan keputusan memilih produk tidak independen secara statistika, tidak tepat untuk membuat kesimpulan secara terpisah.

\section{KARAKTERISTIK LINGKUNGAN DAN PENGARUHNYA}

Ewing dan Cervero (2001) merangkum hasil empiris yang didapatkan dari hubungan antara karakteristik lingkungan dengan perjalanan menggunakan elastisitas. Elastisitas merupakan rasio perubahan proporsi dalam satu variabel yang diasosiasikan dengan perubahan proporsi variabel lainnya. Dalam studinya, variabel yang digunakan sebagai pengukuran dari karakteristik lingkungan antara lain adalah kepadatan, keberagaman, desain, aksesibilitas, dan jarak kepada fasilitas transit. Kepadatan diukur sebagai variabel interes per unit area. Variabel interes dapat berupa populasi, unit hunian, employment, area gedung, dan lain sebagainya. Keberagaman mengukur banyaknya kegunaan lahan yang berada di satuan area dengan ukuran yang direpresentasikan dalam lahan, luas lantai, atau pegawai. Nilai terendah dari keberagaman adalah jika suatu area hanya memiliki satu kegunaan. Sedangkan nilai tertinggi dari keberagaman adalah saat suatu area memiliki banyak kegunaan seperti untuk perumahan, perkantoran, dan komersial. Desain meliputi karakteristik jaringan jalan dalam suatu area, ukuran blok, persimpangan, trotoar, pohon dipinggir jalan, penyeberangan jalan, dan penataan kota lainnya.

Aksesibilitas mengukur kemudahan akses terhadap atraksi perjalanan. Contoh aksesibilitas regional adalah jarak yang paling simpel menuju area bisnis. Jarak ke angkutan publik biasanya diukur sebagai rata-rata dari rute terpendek dari perumahan atau dari tempat kerja menuju stasiun atau halte terdekat. Dapat pula diukur sebagai kepadatan rute, jarak antarperhentian atau jumlah stasiun per unit area.

Analisis terkait hubungan karakteristik lingkungan dengan karakteristik perjalanan juga dilakukan oleh Handy et al. (2005). Dalam studinya, faktor karakteristik lingkungan terdiri atas aksesibilitas, pilihan aktivitas fisik, keamanan, sosialisasi, ruang terbuka, dan atraksi. Karakteristik ini dihubungkan dengan karakteristik preferensi perjalanan. Menurut Handy et al. (2005) jenis analisis yang berbeda dapat menghasilkan jawaban yang berbeda terhadap studi yang dilakukan. Hasil dari studi adalah perbandingan jenis lingkungan yang berbeda menunjukkan variasi yang signifikan dalam tingkat mengemudi. Namun, analisis multivariat data penggalan waktu (cross-sectional) menunjukkan bahwa perbedaan ini sebagian besar dijelaskan oleh sikap dan bahwa efek dari lingkungan binaan sebagian besar hilang ketika faktor sikap dan faktor sosio-demografis telah diperhitungkan. 


\section{METODE PENELITIAN}

Penelitian ini menggunakan kuesioner yang didistribusikan pada pelaku belanja di rumah tangga di Kota Bandung yang merupakan bagian dari studi yang dilakukan oleh Joewono (2017). Kuesioner ini terdiri atas pertanyaan yang mencakup aspek sosiodemografi (antara lain pendapatan, status keluarga, dan status rumah), aspek perilaku belanja termasuk aspek spasial, lokasi belanja, karakteristik perjalanan, serta aspek karakteristik lingkungan terbangun untuk menyelidiki karakteristik lingkungan rumah tangga. Tabel 1 menjelaskan variabel karakteristik lingkungan tempat tinggal.

Tabel 1 Pertanyaan Karakteristik Lingkungan

\begin{tabular}{lcll}
\hline Karakteristik & Variabel & & \multicolumn{1}{c}{ Indikator } \\
\hline Aksesibilitas & $\mathrm{P}_{1}$ & 1 & Akses yang mudah ke tempat belanja \\
& $\mathrm{P}_{2}$ & 2 & Akses yang mudah ke fasilitas \\
& $\mathrm{P}_{3}$ & 3 & Akses yang mudah ke pusat kota \\
& $\mathrm{P}_{4}$ & 4 & Akses yang mudah ke jalan raya \\
& $\mathrm{P}_{5}$ & 5 & Layanan angkutan umum yang banyak \\
& $\mathrm{P}_{6}$ & 6 & Ada rute bersepeda di sekitar rumah \\
Aktivitas Fisik & $\mathrm{P}_{7}$ & 1 & Ada rute berjalan kaki di sekitar rumah \\
& $\mathrm{P}_{8}$ & 2 & Ada taman dan ruang terbuka hijau di sekitar \\
& $\mathrm{P}_{9}$ & 3 & Lingkungan yang tenang \\
Keamanan & $\mathrm{P}_{10}$ & 1 & Penerangan jalan yang baik \\
& $\mathrm{P}_{11}$ & 2 & Tingkat kejahatan yang rendah \\
& $\mathrm{P}_{12}$ & 3 & Sedikit kendaraan yang lalu lalang, aman untuk berjalan kaki, atau \\
& & & aman untuk bermain anak-anak \\
Sosialisasi & $\mathrm{P}_{13}$ & 4 & Lingkungan yang beragam dalam hal budaya, suku, agama, dll. \\
& $\mathrm{P}_{14}$ & 1 & Banyak orang di sekitar lingkungan \\
Luas Ruang & $\mathrm{P}_{15}$ & 2 & Banyak orang di dalam lingkungan \\
Terbuka & $\mathrm{P}_{16}$ & 3 & Interaksi antarwarga yang tinggi \\
Atraksi & $\mathrm{P}_{17}$ & 4 & Tingkat ekonomi yang setara dengan saya \\
& $\mathrm{P}_{18}$ & 5 & Ada taman yang luas di depan dan atau belakang rumah \\
& $\mathrm{P}_{19}$ & 1 & Tersedia lahan parkir di sekitar rumah \\
& $\mathrm{P}_{20}$ & 2 & Tampilan lingkungan yang menarik, \\
& $\mathrm{P}_{21}$ & 1 & Gaya rumah yang beragam \\
& $\mathrm{P}_{22}$ & 2 & Lingkungan yang terawat baik dan banyak pohon besar di sisi jalan \\
\hline
\end{tabular}

Sumber: Joewono (2017)

Secara spesifik, karakteristik lingkungan yang ditanyakan dalam kuesioner terdiri atas 22 pertanyaan dalam 6 grup seperti yang dijelaskan pada Tabel 1. Jawaban terkait karakteristik lingkungan dilakukan dalam skala Likert 1-5 dalam rentang sangat tidak setuju hingga sangat setuju. Skala Likert digunakan untuk mengukur sikap, pendapat, dan persepsi sosial seseorang atau sekelompok orang tentang fenomena social (Arifin, 2017).

Kuesioner dibagikan di enam wilayah administratif Kota Bandung, yaitu Tegallega, Gede Bage, Ujung Berung, Karees, Cibeunying, dan Bojonagara. Pendistribusian dilakukan dari tanggal 10 hingga 16 Juni 2017 dengan bantuan 27 surveyor. Ukuran sampel 400 ditentukan berdasarkan Persamaan Yamane (Israel, 2012) dengan acuan populasi Kota Bandung sebanyak 2.481.469 jiwa (BPS, 2017) dan tingkat signifikansi 5\%. Ukuran sampel ditingkatkan menjadi 520 untuk mengatasi peluang kesalahan selama survei. Untuk keperluan analisis hanya 298 responden yang digunakan dalam analisis. Karakteristik 
responden disajikan pada Tabel 2. Untuk analisis dalam paper ini, variabel yang digunakan dalam model merupakan variabel karakteristik lingkungan, frekuensi belanja, dan karakteristik demografi dan perjalanan. Informasi lebih rinci terkait variabel yang digunakan dapat ditemukan dalam Larasati (2018).

Tabel 2 Karakteristik Responden $(\mathrm{N}=298)$

\begin{tabular}{llr}
\hline & Karakteristik & Proporsi (\%) \\
\hline Pendapatan total keluarga per bulan & Kurang dari Rp3.000.000,00 & 28,19 \\
& Rp3.000.000-Rp6.000.000,00 & 30,54 \\
& Rp6.000.000-Rp9.000.000,00 & 14,77 \\
& Rp9.000.000-Rp12.000.000,00 & 7,72 \\
& Rp12.000.000-Rp15.000.000,00 & 7,05 \\
& Lebih dari Rp15.000.000,00 & 11,74 \\
\hline Frekuensi berbelanja & Satu atau kurang dalam sebulan & 28,19 \\
& Sekali dalam beberapa minggu & 27,85 \\
& Sekali seminggu & 24,83 \\
& Berkali-kali dalam seminggu & 17,11 \\
& Setiap hari & 2,01 \\
\hline Jarak perjalanan & Kurang dari 1 km & 44,63 \\
& 1-5 km & 47,32 \\
& 5-10 km & 6,38 \\
& 10-15 km & 1,34 \\
& Lebih dari 15 km & 0,34 \\
\hline Biaya perjalanan & Kurang dari Rp10.000,00 & 82,21 \\
& Rp10.001-Rp20.000,00 & 10,74 \\
& Rp20.001-Rp30.000,00 & 2,68 \\
& Rp30.001-Rp40.000,00 & 2,35 \\
\hline Moda transportasi & Rp40.001-Rp50.000,00 & 1,01 \\
& Lebih dari Rp50.000,00 & 1,01 \\
\hline
\end{tabular}

Pada Tabel 2 ditampilkan proporsi karakteristik demografi pelaku belanja dari total responden sebanyak 298 orang. Karakteristik pendapatan dan pengeluaran total keluarga responden per bulan sebanyak 30,54\% responden memiliki pendapatan sebesar Rp3.000.000,00 sampai dengan Rp6.000.000,00 untuk setiap bulan. Pendapatan sebesar Rp12.000.000,00 sampai dengan Rp15.000.000,00 memiliki jumlah responden terkecil dengan proporsi responden sebesar 7,05\%. Pengeluaran total keluarga dengan jumlah responden paling sedikit juga terdapat pada kategori rentang tersebut dengan proporsi responden sebanyak $1,68 \%$. Pengeluaran total keluarga per bulan sebesar kurang dari Rp3.000.000,00 menjadi kategori jumlah pengeluaran yang paling banyak dipilih oleh responden dengan proporsi sebesar $41,61 \%$.

Dari 298 responden diketahui bahwa sebagian besar responden melakukan kegiatan berbelanja setiap bulan. Terdapat sebanyak $28,19 \%$ responden menyatakan berbelanja satu atau kurang dalam sebulan. Hanya 2,01\% responden yang melakukan kegiatan berbelanja setiap hari. Tempat belanja yang dituju sebagian besar responden adalah sejauh $1-5 \mathrm{~km}$. Hal tersebut dapat dilihat dari proporsi jawaban responden pada kategori jarak perjalanan 
1-5 km sebesar 47,32\%. Untuk melakukan perjalanan tersebut, 82,21\% dari total responden mengeluarkan biaya perjalanan dengan besaran kurang dari Rp10.000,00. Hanya 2,01\% responden yang mengeluarkan biaya dengan besaran lebih dari Rp40.000,00 untuk biaya perjalanan belanja. Moda transportasi yang paling banyak digunakan pelaku belanja adalah sepeda motor dengan proporsi 43,96\%. Moda transportasi kereta menjadi moda yang paling sedikit dipilih oleh pelaku belanja. Hal ini terkait dengan jarak perjalanan yang ditempuh oleh sebagian besar pelaku belanja, yaitu sejauh $1 \mathrm{~km}$ sampai dengan $5 \mathrm{~km}$.

Tabel 3 Model Ordinal Logit Frekuensi Perjalanan dan Karakteristik Lingkungan

\begin{tabular}{|c|c|c|c|c|}
\hline & Variabel & Estimate & T-Statistics & P-Value \\
\hline & Frekuensi Berbelanja & & & \\
\hline \multirow[t]{4}{*}{ Treshold } & Satu atau kurang dalam sebulan & $-1,100$ & $-1,410$ & 0,160 \\
\hline & Sekali dalam beberapa minggu & 0,250 & 0,321 & 0,750 \\
\hline & Sekali seminggu & 1,650 & 2,115 & 0,040 \\
\hline & Berkali-kali dalam seminggu & 4,360 & 4,955 & 0,000 \\
\hline Akses yang mudah & $\begin{array}{l}\text { Variabel Karakteristik Lingkungan dan Personal } \\
{[\mathrm{P} 1=1]}\end{array}$ & $-0,620$ & $-0,320$ & 0.750 \\
\hline ke tempat belanja & {$[\mathrm{P} 1=2]$} & 3,530 & 3,879 & 0,000 \\
\hline Akses yang mudah & {$[\mathrm{P} 1=3]$} & 1.580 & 2,431 & 0,010 \\
\hline \multirow[t]{2}{*}{ ke jalan raya } & {$[\mathrm{P} 1=4]$} & 1,060 & 2,524 & 0,010 \\
\hline & {$[\mathrm{P} 4=2]$} & $-1,100$ & $-1,594$ & 0,110 \\
\hline Ada taman dan & {$[\mathrm{P} 4=3]$} & $-0,670$ & $-1,136$ & 0,260 \\
\hline ruang terbuka hijau & {$[\mathrm{P} 4=4]$} & $-0,740$ & $-1,850$ & 0,070 \\
\hline \multirow[t]{2}{*}{ di sekitar } & {$[\mathrm{P} 8=1]$} & 2,420 & 2,689 & 0,010 \\
\hline & {$[\mathrm{P} 8=2]$} & 1,560 & 2,889 & 0,000 \\
\hline \multirow{3}{*}{$\begin{array}{l}\text { Lingkungan yang } \\
\text { tenang }\end{array}$} & {$[\mathrm{P} 8=3]$} & $\begin{array}{l}1,500 \\
1,050\end{array}$ & $\begin{array}{l}2,009 \\
1,842\end{array}$ & $\begin{array}{l}0,070 \\
0,070\end{array}$ \\
\hline & {$[\mathrm{P} 8=4]$} & 0,940 & $\begin{array}{l}1,042 \\
1,843\end{array}$ & 0,060 \\
\hline & {$[\mathrm{P} 9=1]$} & 0,420 & 0,356 & $\begin{array}{l}0,000 \\
0,720\end{array}$ \\
\hline \multirow{6}{*}{$\begin{array}{l}\text { Lingkungan yang } \\
\text { beragam dalam hal } \\
\text { budaya. suku. dan } \\
\text { agama Banyak } \\
\text { orang di sekitar } \\
\text { lingkungan }\end{array}$} & {$[\mathrm{P} 9=2]$} & $-1,120$ & $-2,113$ & 0,030 \\
\hline & {$[\mathrm{P9}=3]$} & 0,060 & 0,122 & 0,900 \\
\hline & {$[\mathrm{P} 9=4]$} & $-0,410$ & $-0,976$ & 0,330 \\
\hline & {$[\mathrm{P} 13=1]$} & $-1,290$ & $-0,600$ & 0,550 \\
\hline & $\begin{array}{l}{[\mathrm{P} 13=2]} \\
{[\mathrm{P} 13=3]}\end{array}$ & $-1,230$ & $-1,922$ & 0,060 \\
\hline & $\begin{array}{l}{[\mathrm{P} 13=3]} \\
{[\mathrm{P} 13=4]}\end{array}$ & $-0,100$ & $-0,208$ & $\begin{array}{l}0,000 \\
0,840\end{array}$ \\
\hline \multirow{4}{*}{$\begin{array}{l}\text { Interaksi antarwarga } \\
\text { yang tinggi }\end{array}$} & {$[\mathrm{P} 14=2]$} & $-0,480$ & $-1,143$ & 0,260 \\
\hline & {$[\mathrm{P} 14=3]$} & 1,660 & 2,213 & 0,030 \\
\hline & {$[\mathrm{P} 14=4]$} & 0,370 & 0,617 & 0,530 \\
\hline & {$[\mathrm{P} 16=1]$} & 0,380 & 0,776 & 0,440 \\
\hline \multirow{3}{*}{$\begin{array}{l}\text { Gaya rumah yang } \\
\text { beragam }\end{array}$} & {$[\mathrm{P} 16=2]$} & 0,250 & 0,207 & 0,840 \\
\hline & [P16=3] & $-1,070$ & $-1,981$ & 0,050 \\
\hline & {$[\mathrm{P} 16=4]$} & $-0,760$ & $-1,652$ & 0,100 \\
\hline \multirow{5}{*}{$\begin{array}{l}\text { Lingkungan yang } \\
\text { terawat baik dan } \\
\text { banyak pohon besar } \\
\text { di sisi jalan }\end{array}$} & {$[\mathrm{P} 21=1]$} & $-0,550$ & $-1,375$ & 0,160 \\
\hline & {$[\mathrm{P} 21=2]$} & $-4,30$ & $-2,363$ & 0,020 \\
\hline & {$[\mathrm{P} 21=3]$} & $-1,380$ & $-1,683$ & 0,090 \\
\hline & {$[\mathrm{P} 21=4]$} & $-0,900$ & $-1,184$ & 0,240 \\
\hline & {$[\mathrm{P} 22=1]$} & $-1,070$ & $-1,446$ & 0,150 \\
\hline \multirow{12}{*}{$\begin{array}{l}\text { Pendapatan total } \\
\text { keluarga per bulan }\end{array}$} & {$[\mathrm{P} 22=2]$} & 1,010 & 0,918 & 0,360 \\
\hline & {$[\mathrm{P} 22=3]$} & 1,380 & 2,000 & 0,050 \\
\hline & $\begin{array}{l}{[\mathrm{P} 22=4]} \\
{[\mathrm{D} 2=1]}\end{array}$ & 1,180 & 1,761 & 0,080 \\
\hline & $\begin{array}{l}{[\mathrm{D} 2=1]} \\
{[\mathrm{D} 2=2]}\end{array}$ & 0,970 & 1,492 & 0,140 \\
\hline & $\begin{array}{l}{[\mathrm{DL}=2]} \\
{[\mathrm{D} 2=3]}\end{array}$ & $-0,330$ & $-0,846$ & 0,400 \\
\hline & $\begin{array}{l}{[\mathrm{DL}=3]} \\
{[\mathrm{D} 2=4]}\end{array}$ & $-0,710$ & $-1,868$ & 0,070 \\
\hline & $\begin{array}{l}{[\mathrm{D} 2=4]} \\
{[\mathrm{D} 2=5]}\end{array}$ & $-0,640$ & $-1,488$ & 0,140 \\
\hline & & $-0,990$ & $-1,833$ & 0,060 \\
\hline & & $-0,730$ & $-1,377$ & 0,170 \\
\hline & -2LL (0); -2LL ( $\beta) ;[\chi 2 ;$ df.;p-value] & \multicolumn{2}{|c|}{$\begin{array}{l}816,580 ; 751,30 \\
{[65,28 ; 39 ; 0,000]}\end{array}$} & \\
\hline & Cox and Snell $\mathrm{R}^{2}$; Nagelkerke $\mathrm{R}^{2}$; McFadden $\mathrm{R}^{2}$ & \multicolumn{2}{|c|}{$[0,200 ; 0,210 ; 0,080]$} & \\
\hline & Test of Parallel Lines [ $\chi 2 ; \mathrm{df} . ; \mathrm{p}$-value] & \multicolumn{2}{|c|}{$[123,31 ; 117 ; 0,330]$} & \\
\hline
\end{tabular}




\section{ANALISIS}

Estimasi model regresi ordinal antara variabel frekuensi berbelanja dengan variabel karakteristik lingkungan tempat tinggal dengan juga mempertimbangkan karakteristik pelaku belanja. Karakteristik pelaku belanja terdiri atas faktor demografi dan perjalanan berbelanja pelaku belanja. Setelah melalui proses step-wise, dari seluruh variabel tambahan yang dimasukkan, hanya faktor pendapatan total keluarga per bulan yang signifikan berdasarkan hasil uji kesesuaian model. Tabel 3 menyajikan uji kesesuaian setelah dilakukan penambahan variabel demografi. Pada model tersebut terjadi penurunan nilai -2 log likelihood sebesar 65,28 dengan nilai signifikansi sebesar 0,01. Nilai signifikansi lebih kecil dari nilai $5 \%$ yang berarti model dengan memasukkan variabel bebas adalah sesuai. Uji selanjutnya adalah kesesuaian pemilihan model menggunakan uji parallel lines. Uji parallel lines menunjukkan bahwa pemilihan model link function logit adalah tepat.

Berdasarkan nilai estimasi yang didapat, seperti terlihat pada Tabel 3, pelaku belanja yang sangat tidak setuju dengan lingkungan yang memiliki akses nampak bahwa yang mudah ke tempat berbelanja berbanding terbalik dengan frekuensi berbelanja. Sedangkan pilihan tidak setuju sampai setuju memiliki hubungan searah dengan frekuensi berbelanja, namun tren dari nilai estimasi model regresinya menurun. Hal ini menunjukkan bahwa semakin baik pelaku belanja dengan lingkungan tempat tinggal yang baik cenderung memiliki frekuensi belanja yang tinggi.

Responden yang menyatakan akses yang mudah ke jalan raya dengan variabel frekuensi berbelanja menunjukkan hubungan tidak searah walaupun nilai koefisiennya menurun. Pelaku belanja yang tinggal dengan akses yang tidak terlalu mudah ke jalan raya lebih sering melakukan perjalanan belanja. Pelaku belanja yang tinggal dengan taman dan ruang terbuka hijau di sekitar tempat tinggal memiliki hubungan yang searah dengan frekuensi berbelanja. Hal ini berarti tanggapan pelaku belanja terhadap lingkungan tempat tinggal berbanding lurus dengan frekuensi berbelanja yang dilakukan.

Pelaku yang tinggal di lingkungan yang tenang memiliki hubungan yang tidak searah dengan frekuensi belanja. Adapun pelaku yang tinggal di lingkungan yang beragam dalam hal budaya, suku, dan agama menunjukkan adanya kencenderungan hubungan yang berbanding terbalik dengan frekuensi berbelanja. Di sisi lain, pelaku belanja yang mempunyai kepadatan lingkugan yang padat di sekitar tempat tinggal memiliki hubungan searah dengan frekuensi berbelanja. Semakin setuju pelaku belanja dengan lingkungan tempat tinggal yang banyak orang semakin tinggi frekuensi berbelanja yang dilakukan. Selanjutnya lingkungan dengan interaksi antarwarga yang tinggi memiliki hubungan tidak searah dengan frekuensi belanja. Variabel pendapatan total keluarga per bulan memiliki hubungan tidak searah dengan frekuensi berbelanja. Hal ini berarti semakin tinggi pendapatan total keluarga per bulan, maka frekuensi berbelanja pelaku belanja semakin rendah.

\section{DISKUSI}

Studi ini mencoba menginvestigasi pengaruh karakteristik lingkungan terhadap frekuensi perjalanan berbelanja. Selain mengonfirmasi temuan studi sebelumnya, studi ini 
menegaskan pemahaman tentang pengaruh karakteristik lingkungan terhadap perilaku belanja. Sejalan dengan Handy et al. (2005) yang menemukan bahwa perubahan dalam berkendara dan perubahan built environmental menunjukkan hubungan yang signifikan. Pada model frekuensi berbelanja dengan karakteristik lingkungan tempat tinggal, dalam studi ini ditemukan bahwa tidak semua variabel karakteristik lingkungan berpengaruh signifikan di dalam model. Variabel yang berpengaruh negatif adalah akses ke jalan raya, keberagaman lingkungan, dan keberagaman gaya rumah. Variabel keberadaan taman dan ruang terbuka hijau, banyak orang di sekitar lingkungan, serta lingkungan yang terawat baik dan banyak pohon memiliki hubungan positif dengan frekuensi berbelanja. Sedangkan variabel akses dari rumah ke tempat berbelanja memiliki hubungan positif pada frekuensi berbelanja. Hubungan positif juga ditemukan pada variabel lingkungan tempat tinggal yang tenang dan lingkungan dengan interaksi antarwarga yang tinggi. Hal ini sejalan dengan studi Joewono et al. (2019) yang menyatakan bahwa karakteristik lingkungan dengan kualitas tinggi akan memiliki karakteristik perjalanan yang berbeda dengan karakteristik lingkungan yang rendah. Hal ini berkaitan dengan keadaan sosiodemografi pada kedua karakteristik lingkungan tersebut yang berbeda.

Selanjutnya, model menunjukkan bahwa hubungan yang ditemukan berpengaruh signifikan adalah sama antara model yang melibatkan variabel sosiodemografi dengan model tanpa variabel sosiodemografi. Variabel sosiodemografi yang ditemukan berpengaruh adalah pendapatan total keluarga per bulan. Ditemukan bahwa responden yang memiliki pendapatan tinggi berasosiasi dengan jumlah frekuensi perjalanan yang rendah. Hal ini berarti semakin tinggi pendapatan total keluarga per bulan, maka frekuensi berbelanja pelaku belanja semakin rendah. Temuan ini sejalan dengan Ewing dan Cervero (2001) menyatakan bahwa frekuensi perjalanan sebagian besar tidak tergantung hanya pada variabel penggunaan lahan, namun juga bergantung pada karakteristik sosioekonomi rumah tangga. Penurunan dalam penggunaan mobil pribadi dengan aksesibilitas, kerapatan, atau keberagaman yang lebih besar dipengaruhi oleh peningkatan angkutan publik, berjalan, atau perjalanan bersepeda. Oleh karena itu, dalam studi ini ditambahkan faktor demografi pelaku belanja untuk mengembangkan model frekuensi dengan karakteristik lingkungan tempat tinggal.

\section{KESIMPULAN}

Studi ini mengonfirmasi studi sebelumnya bahwa karakteristik lingkungan berpengaruh terhadap perilaku belanja. Temuan tersebut mengindikasikan bahwa kebijakan tata ruang memerlukan penanganan dalam rangka penurunan aktivitas belanja sesuai dengan karakteristik lingkungan yang ada. Pemenuhan karakteristik tempat tinggal tertentu memerlukan pemenuhan dalam rangka membuat pola ruang yang efektif untuk meminimalkan perjalanan belanja. Hal ini mendukung studi Rizki dan Joewono (2019) yang menyatakan bahwa pola lokasi belanja memerlukan penyesuaian dengan karakteristik lokasi aktivitas salah satunya tempat tinggal. 
Meskipun telah banyak informasi yang diperoleh dalam studi ini, namun terdapat keterbatasan dalam analisis pada studi ini. Studi ini hanya melakukan analisis secara satu arah dengan karakteristik lingkungan. Di sisi lain karakteristik lingkungan sangat berhubungan dengan grup masyarakat tertentu. Perlu studi lebih lanjut untuk mengeksplorasi karakteristik lingkungan tempat tinggal terutama yang mengakomodasi klasifikasi masyarakat yang lebih beragam. Selanjutnya studi tentang perilaku perjalaan berbelanja perlu dipelajari dengan menambahkan faktor psikologis, misal motivasi untuk melakukan kegiatan berbelanja. Pemahaman yang lebih dalam pada perilaku belanja akan menambah pengetahuan untuk merumuskan kebijakan transportasi untuk meminimalisasi dampak negatif dari perjalanan berbelanja.

\section{UCAPAN TERIMA KASIH}

Studi ini didanai oleh Direktorat Penelitian dan Pengabdian Masyarakat, Direktorat Jenderal Penguatan Riset dan Pengembangan, Kementerian Riset, Teknologi, dan Pendidikan Tinggi, Republik Indonesia Kontrak Riset No. 1598/K4/KM/2017. Penulis mengucapkan terima kasih kepada semua pihak yang telah berpartisipasi dalam pengumpulan data.

\section{DAFTAR PUSTAKA}

Arentze, T.A., Borgers, A.W.J., dan Timmermans, H. J. P. 1993. A Model of Multipurpose Shopping Trip Behavior. Regional Science, 72 (3): 239-256.

Arifin, J. 2017. SPSS 24 untuk Studi dan Skripsi. Jakarta: PT Elex Media Komputindo. Badan Pusat Statistik Kota Bandung. 2017. Kota Bandung dalam Angka 2017. Bandung.

Ewing, R. dan Cervero, R. 2001. Travel and the Built Environment: A Synthesis. Transportation Research Record: Journal of the Transportation Research Board, 1780: 87-114.

Handy, S., Cao, X., dan Mokhtarian, P.L. 2005. Correlation or Causality between the Built Environment Evidence from Northern California and Travel Behavior? Evidence from Northern California, Transportation Research Part D: 10, 427-444.

Israel, G.D. 2012. Determining Sample Size, PEOD6, Agricultural Education dan Communication Department. Florida Cooperative Extension Service, Institute of Food dan Agricultural Sciences, University of Florida, Gainesville, FL.

Joewono, T.B. 2017. Interaksi ICT, Perjalanan Belanja, dan Penggunaan Angkutan Publik. Hibah Studi Unggulan Perguruan Tinggi: Laporan Studi, Universitas Katolik Parahyangan, Bandung.

Joewono, T. B., Tarigan, A. K., dan Rizki, M. 2019. Segmentation, Classification, and Determinants of In-Store Shopping Activity and Travel Behaviour in the Digitalisation Era: The Context of a Developing Country. Sustainability, 11 (6): 1591. 
Larasati, N. P. 2018. Hubungan Karakteristik Lingkungan Tempat Tinggal terhadap Karakteristik Perjalanan Berbelanja di Kota Bandung. Skripsi tidak diterbitkan. Program Studi Teknik Sipil, Fakultas Teknik, Universitas Katolik Parahyangan.

McFadden, D. 1973. Conditional Logit Analysis of Qualitative Choice Behaviour. Frontiers in Econometrics, 105-142.

Pandin, M.L. 2009. Potret Bisnis Ritel di Indonesia: Pasar Modern. Economic Review, 215: $1-12$.

Rizki, M. dan Joewono, T.B. 2019. Pemilihan Lokasi Belanja dan Perilaku Perjalanan di Kota Bandung. Jurnal Transportasi, 19 (1): 67-76.

Soliha, E. 2008. Analisis Industri Ritel di Indonesia. Jurnal Bisnis dan Ekonomi, 15 (2): $128-142$.

Vickerman, R.W. dan Barmby, T.A. 1984. The Structure of Shopping Travel: Some Develoments of the Trip Generation Model. Journal of Transport Economics and Policy 18 (2): 109-121. 